Int. J. Odontostomat., 10(1):7-10, 2016.

\title{
Oral Manifestations in Adolescents and Their Impact on Social Discrimination
}

\author{
Manifestaciones Orales en Adolescentes, \\ Su Impacto con la Discriminación Social
}

\begin{abstract}
Ameyalli Jocelyn Martínez Delgado*; Gustavo Israel Martínez González; Sonia Martha López Villarreal ${ }^{\star}$ \& Osvelia Esmeralda Rodríguez Luis
\end{abstract}

\begin{abstract}
MARTíNEZ, D. A. J.; MARTÍNEZ, G. G. I.; LÓPEZ, V. S. M. \& RODRíGUEZ, L. O. E. Oral manifestations in adolescents and their impact on social discrimination. Int. J. Odontostomat., 10(1):7-10, 2016.

ABSTRACT: Adolescents between 12 and 13 years of age suffer social discrimination and low self-esteem because of their physical appearance. The objective of this study was to evaluate the presence of oral manifestations such as dental malposition, gummy smile, halitosis, and bone malformations of the maxillary and jaw, and determine their social impact on adolescents. A descriptive study was performed in secondary school adolescents between 12 and 13 years of age. First, an interview was carried out to identify the impact of oral manifestations as a cause of social discrimination and then clinical examination was performed. It was found that in adolescents, oral manifestations cause social discrimination. Dental malposition was the main cause (81\%), followed by gummy smile (29\%), maxillary and jaw bone malformations (16 \%) and halitosis $(11 \%)$. Of those interviewed, $90 \%$ expressed having received negative comments about their oral cavity and $81 \%$ referred the need for dental care; $72 \%$ felt discriminated by their classmates and $65 \%$ did not like to speak in public ( $p$ $<0.005)$. It was concluded that a relationship exists between oral manifestations and social discrimination in adolescents.
\end{abstract}

KEY WORDS: odontology, public health, malposition, adolescent, bullying, discrimination.

\section{INTRODUCTION}

Adolescents feel that their rights have been violated because of their physical appearance, a matter that was identified in $24.5 \%$ of adolescents in the National Survey on Discrimination in Mexico (Consejo Nacional para Prevenir la Discriminación, 2011a). Therefore, facial harmony is an important factor in the health and quality of life of these individuals. Facial and occlusal disharmony cause negative effects in adolescents at a time in life when adolescents overreact to problems of personal appearance (Gutiérrez Reina et al., 2008). Puberty begins at this stage, and for many, it is a period of turbulence that is accompanied by shame, a feeling that is magnified by the fear that others will discover that they are insecure. One of the main concerns of adolescents is the need to find a new identity and this includes several elements, such as physical appearance and social acceptance (Blum et al., 2012).

Among the oral manifestations that can cause social problems is halitosis, defined as an unpleasant breath odor that is frequently related to bad oral hygiene. This condition causes insecurity and shame and affects personal relationships (Hechavarria Martínez et al., 2014). Another is dental malposition, defined as any alteration or occlusal disorder caused by esthetic, ethnic and cultural factors (Aguilar \& Taboada, 2013). The gummy smile has also been described as a condition in which more than $2 \mathrm{~mm}$ of gingival tissue is exposed when a person smiles. Etiologically, it is caused by dental, skeletal and soft tissue factors, producing a disagreeable effect that causes individuals to cover their mouths or to avoid smiling. This has a negative effect on the person, altering their facial expression and sometimes triggering behavioral problems (Chacón Martínez et al., 2011). Lastly, bone malformations of the maxillary and jaw are alterations that occur during organogenesis and can be caused by environmental and genetic factors (Sadler, 2010). Prognathism is characterized by protrusion of the middle third of the face in relation to the maxillary bone (Palomeque Blacutt et al., 2014). Hypoplasia of the su-

"Facultad de Odontología, Universidad Autónoma de Nuevo León, Nuevo León, México. 
perior maxillary is characterized by a sagittal, vertical and transverse deficiency of the maxillary bone (Meneses \& Botero, 2012).

Discrimination denies people equal liberties, rights, and opportunities. It excludes individuals and hinders them from reaching their full potential, placing them in a situation of high vulnerability. This systematic, unjust and undeserved disadvantage causes adolescents who suffer oral problems to be more and more susceptible to having their rights violated in the future (Consejo Nacional para Prevenir la Discriminación, 2011b). On the other hand, bullying is an aggressive, deliberate and repetitive harassment of one student by another due to race, religion, social position, physical structure or age (United Nations Organization, 2006).

Social problems in adolescents of the state of Nuevo Leon have increased. This is due to the parent's lack of information of the manifestations of dental diseases such as halitosis, gummy smile, dental malposition, and bone malformations, among others, in adolescents. This, combined with the poor care provided to adolescents, causes a high incidence, which is an important cause of discrimination. The objective of this study is to evaluate adolescents' physical appearance and the presence of oral manifestations and their social impact with the purpose of collecting data on dental problems that trigger social discrimination to propose solutions and alternatives to achieve equality and respect.

\section{MATERIAL AND METHOD}

This was a descriptive cross-sectional study previously authorized by the Bioethics Committee (SPSI-010613, no. 0064) that was performed in a secondary school in Monterrey, Nuevo Leon with adolescents that met inclusion criteria with an age range of 12 to 13 years that attended the first year of school and who presented oral manifestations. Informed consent for participation was obtained from the parents or tutors. Adolescents with systemic disorders, under dental or psychological treatment, and those who refused to participate in the study and had incomplete surveys were excluded. The final sample was composed of 62 adolescents.

A Likert-scale survey of 40 questions, distributed into 6 sections, was constructed and validated, identifying the clarity and pertinence indexes for validity of the construct of interest. Questions started with general data of the adolescent, followed by a section that identified the presence of social discrimination with relation to aspects of the face, teeth, gummy smile, and bad breath (36 questions); finally, the adolescents' perception of their physical appearance was identified. Clinical examination of the adolescents was performed using the clinical record to corroborate the existence of the previously described oral manifestations. For examination, a number five mouth mirror, a $6 \mathrm{~mm}$ Williams-periodontal probe, and dental floss without wax were used.

\section{RESULTS AND DISCUSSION}

The group consisted of adolescents between the ages of 12 and 13 years; of these, $56 \%$ were girls and $44 \%$ boys (Table I). Regarding the different oral manifestations, $81 \%$ had dental malposition (Table II), mainly Class I Angle's malocclusion. Based on this, 60 $\%$ perceived social discrimination and $74 \%$ received negative comments about their oral cavity due to dental malposition. We deduced that dental malposition negatively influenced the adolescent's physical appearance $(p<0.05)$ (Table III). Previous research supports these results mentioning that adolescents with mild malocclusion have an inferiority complex; in addition, the appearance of their teeth caused taunting that made them withdraw from activities. It was also established that a small orthognathic deformity can cause psychological alterations and social discomfort in the individual (Gutiérrez Reina et al.). Choi et al. (2014) pointed out that malocclusion is a key factor associated with poor quality of life caused by limited oral function, pain and social disability. Taghavi Bayat et al. (2013) mentioned that low self-esteem seemed to be related to concerns about the presence of malocclusion in adolescents and they looked for different strategies to face this concern such as hiding their teeth and trying to receive orthodontic treatment. Malocclusion problems found in this study probably developed because of inadequate maxillary growth, since $16 \%$ of the adolescents examined had bone malformations of the maxillary and jaw; of these $8 \%$ had mandibular prognathism and $5 \%$ hypoplasia of the upper maxillary (Table II). The literature has reported that maxillary malformations are associated with dentofacial disproportions that affect the facial appearance of the individual, and correct dental occlusion, mastication, swallowing, phonation and facial symmetry. The main concern in these patients is their effect on social interrelations which cause psychological problems, since 
the patient is dissatisfied with his/her appearance (Palomeque Blacutt et al.).

On the other hand, halitosis predominated in $11 \%$ of our respondents (Table II). Suzuki et al. (2008) corroborates that halitosis is a common problem in humans and that it is associated with the status of the oral cavity and the poor psychological condition of the person who suffers it.

With regard to gummy smile, this was found in $29 \%$ of the evaluated adolescents (Table II). Chacón Martínez et al. describe that gummy smile produces an anti-esthetic appearance that makes people cover their mouths or avoid smiling to hide the problem. This negatively affects the individual altering spontaneous facial expression and, on

Table I. Age and sex of adolescents $(n=62)$.

\begin{tabular}{lcccccc}
\hline \multirow{2}{*}{ Age } & \multicolumn{4}{c}{ Sex } & \multicolumn{2}{c}{ Total } \\
\cline { 2 - 7 } & $\mathbf{F}^{*}$ & $\%$ & $\mathbf{F}^{*}$ & $\%$ & $\mathbf{F}^{*}$ & $\%$ \\
\hline 12 & 11 & 18 & 13 & 21 & 24 & 39 \\
13 & 24 & 39 & 14 & 23 & 38 & 61 \\
Total & 35 & 56 & 27 & 44 & 62 & 100 \\
\hline F* $^{*}$ Frequency. & & & & &
\end{tabular}

Table II. Presence of oral manifestations based on sex $(n=62)$.

\begin{tabular}{lcccccc}
\hline \multirow{2}{*}{ Oral manifestations } & \multicolumn{7}{c}{ Sex } \\
& \multicolumn{2}{c}{ Male } & \multicolumn{3}{c}{ Female } & \multicolumn{2}{c}{ Total } \\
\cline { 2 - 7 } & $\mathbf{F}^{*}$ & $\%$ & $\mathbf{F}^{*}$ & $\%$ & $\mathbf{F}^{*}$ & $\%$ \\
\hline Dental malposition & 24 & 39 & 26 & 42 & 50 & 81 \\
Gummy smile & 8 & 13 & 10 & 16 & 18 & 29 \\
Halitosis & 5 & 8 & 2 & 3 & 7 & 11 \\
Malformation & 4 & 6 & 6 & 10 & 10 & 16 \\
Hypoplasia of the upper & & & & & & \\
maxillary & 1 & 2 & 2 & 3 & 3 & 5 \\
Mandibular prognathism & 3 & 5 & 4 & 6 & 7 & 11 \\
\hline
\end{tabular}

$\mathrm{X}^{2}=20.512, \mathrm{p}<0.05, \mathrm{~F}^{*}=$ Frequency.

Table III. Impact of dental malposition on the physical appearance of adolescents $(n=62)$.

\begin{tabular}{lcccc}
\hline \multirow{2}{*}{ Physical appearance } & \multicolumn{3}{c}{ Oral manifestations } \\
& \multicolumn{2}{c}{ Present } & \multicolumn{2}{c}{ Not present } \\
\cline { 2 - 5 } & $\mathbf{F}^{*}$ & $\%$ & $F^{*}$ & $\%$ \\
\hline Teeth & 35 & 56 & 6 & 10 \\
\hline
\end{tabular}

occasion, complex behavior. They also reported that when individuals are subjected to correction, their appearance and self-esteem improves.

The validation process of the questionnaire produced a Cronbach's alpha of 0.84 . This implies that the questionnaire used is a reliable instrument since Soler Cárdenas \& Soler Pons (2012) evidenced that a value close to 1 demonstrates greater reliability of the instrument.

Aguilar \& Taboada mention that alterations of form and physical appearance reduce quality of life and can be a negative factor in the emotional balance of the adolescent since it threatens harmony and esthetics. In this study, $65 \%$ of adolescents did not want to speak in public, $90 \%$ mentioned negative comments regarding their oral appearance, $81 \%$ expressed the need for dental care due to their oral condition, and $72 \%$ felt they were rejected by their peers. At the same time, a relationship between the identified oral manifestations and the need to change their oral condition was found ( $p$ $=0.00000001)$ (Table IV).

\section{CONCLUSION}

In this study, dental malposition was identified as the main oral alteration in adolescents, with this causing a negative impact on their physical appearance and triggering social discrimination. It is suggested to design awareness campaigns for the previously mentioned oral manifestations for the family to obtain opportune and preventive care for adolescents to reduce the rate of social discrimination.

ACKNOWLEDGEMENTS. We thank the Ministry of Education for their support granted through PRODEP 2014.

Table IV. Presence of oral manifestations in adolescents that they do not like and its relationship with changing their oral condition $(n=62)$.

\begin{tabular}{lcccccccccc}
\hline \multirow{2}{*}{ Need for change } & \multicolumn{8}{c}{ Oral Manifestations } \\
& \multicolumn{1}{c}{ Oral breath } & \multicolumn{1}{c}{ Teeth } & \multicolumn{1}{c}{ Smile } & Form of the face & \multicolumn{2}{c}{ Total } \\
\cline { 2 - 12 } & $\mathbf{F}^{*}$ & $\%$ & $\mathbf{F}^{*}$ & $\%$ & $\mathbf{F}^{*}$ & $\%$ & $\mathbf{F}^{*}$ & $\%$ & $\mathbf{F}^{*}$ & $\%$ \\
\hline Oral breath & 3 & 5 & 2 & 3 & 0 & 0 & 3 & 5 & 8 & 13 \\
Teeth & 0 & 0 & 32 & 52 & 1 & 2 & 2 & 3 & 35 & 57 \\
Smile & 0 & 0 & 4 & 6 & 3 & 5 & 0 & 0 & 7 & 11 \\
Form of the face & 2 & 3 & 3 & 5 & 0 & 0 & 7 & 11 & 12 & 19 \\
Total & 5 & 8 & 41 & 66 & 4 & 7 & 12 & 19 & 62 & 100 \\
\hline
\end{tabular}

$\mathrm{X}^{2}=53.54, \mathrm{p}=(0.00000001), \mathrm{F}^{*}=$ Frequency. 
MARTÍNEZ, D. A. J.; MARTÍNEZ, G. G. I.; LÓPEZ, V. S. M. \& RODRÍGUEZ, L. O. E. Manifestaciones orales en adolescentes, su impacto con la discriminación social. Int. J. Odontostomat., 10(1):7-10, 2016.

RESUMEN: Actualmente los adolescentes entre 12 y 13 años sufren discriminación social y por ende baja autoestima, debido al bullying provocado por el aspecto físico. Evaluar la presencia de manifestaciones orales como, malposición dental, sonrisa gingival, halitosis, malformaciones óseas del maxilar y mandíbula y su impacto en la discriminación social de los adolescentes. Se realizó un estudio descriptivo en adolescentes entre 12 y 13 años que cursaban nivel básico, primeramente se aplicó una entrevista para identificar el impacto de las manifestaciones orales como desencadenantes de discriminación social seguido de un examen clínico. Se identificó que existe discriminación social en los adolescentes debido a las manifestaciones orales. La malposición dental fue la principal desencadenante $(80,65 \%)$, seguido de sonrisa gingival $(29,03 \%)$, malformaciones óseas del maxilar y la mandíbula (16,13\%) y halitosis (11,29 \%). El 90,33 \% de los encuestados expresó haber recibido comentarios negativos acerca de su cavidad oral y el $80,65 \%$ refirió la necesidad de atención odontológica. Se han sentido discriminados por sus compañeros $72,20 \%$ y no les gusta hablar en público $64,52 \%$ ( $p<0,005)$. Es posible concluir que existe relación entre las manifestaciones orales que presentaron los adolescentes y que impactan en su discriminación social, ya que expresaron sentir discriminación por sus compañeros, por lo que les gustaría cambiar su aspecto físico.

PALABRAS CLAVE: odontología, salud pública, malposición, adolescente, bullying, discriminación.

\section{REFERENCES}

Aguilar, M. N. A. \& Taboada, A. O. Frequency of malocclusions in association with body posture problems in a school-age population from the State of Mexico. Bol. Med. Hosp. Infant. Mex., 70(5):364-71, 2013.

Blum, V. E. \& Sánchez, G. N. Manual de psicología y desarrollo profesional. Monterrey, Universidad Autónoma de Nuevo León, 2012. pp.54-6.

Consejo Nacional para Prevenir la Discriminación. Encuesta Nacional sobre Discriminación en México - ENADIS 2010. Resultados sobre Las y Los Jóvenes. México D. F., Instituto Mexicano de la Juventud, 2011a. Available from: http:// www.conapred.org.mx/userfiles/files/Enadis-JOVENESAccss.pdf

Consejo Nacional para Prevenir la Discriminación. National Survey on Discrimination in Mexico - ENADIS 2010. Overall Results. México D. F., Instituto Mexicano de la Juventud, 2011b. Available from: http://www.conapred.org.mx/userfiles/files/ENADIS-2010Eng-OverallResults-NoAccss.pdf.

Chacón Martínez, H.; Castro Govea, Y.; Pérez Porras, S.; Vázquez Costilla, O.; González Cárdenas, H. R. \& Mendoza Adam, G. Simplificando el tratamiento quirúrgico de la sonrisa gingival. Cir. Plást. Iberolatinoam., 37(1):43-9, 2011.

Choi, S. H.; Kim, B. I.; Cha, J. Y. \& Hwang, C. J. Impact of malocclusion and common oral diseases on oral health-related quality of life in young adults. Am. J. Orthod. Dentofacial Orthop., 147(5):587-95, 2014.

Gutiérrez Reina, Y.; Expósito Martín, I.; Jiménez Macías, I.; Estrada Verdeja, V. \& Martín Zaldívar, L. Presencia de maloclusiones en adoloscentes y su relación con determinados factores psicosociales. Arch. Méd. Camagüey, 12(5):1-10, 2008.

Hechavarria Martínez, B. O.; Ramón Jiménez, R. \& Méndez Nápoles, Y. Repercusión social de la halitosis. MEDISAN, 18(10):14606, 2014
Meneses, D. \& Botero, P. Alternativas para el tratamiento de hipoplasias maxilares. Rev. CES Odontol., 25(1):64-81, 2012.

Palomeque Blacutt, F.; Aviles Escalera, O. \& Mayta Jiménez, M. Corrección quirúrgica del prognatismo mandibular a propósito de dos casos. Scientifica, 12(1):83-7, 2014.

Sadler, T. W. Langman's Medical Embryology. Philadelphia, Lippincott Williams \& Wilkins, 2010. pp.113-24

Soler Cárdenas, S. F. \& Soler Pons, L. Uso del coeficiente alfa de Cronbach en el análisis de instrumentos escritos. Rev. Méd. Electrón., 34(1):1-6, 2012.

Suzuki, N.; Yoneda, M.; Naito, T.; Iwamoto, T. \& Hirofuji, T. Relationship between halitosis and psychologic status. Oral Surg. Oral Med. Oral Pathol. Oral Radiol. Endod., 106(4):5427, 2008.

Taghavi Bayat, J.; Hallberg, U.; Lindblad, F.; Huggare, J. \& Mohlin, B. Daily life impact of malocclusion in Swedish adolescents: a grounded theory study. Acta Odontol. Scand., 71(3-4):792-8, 2013.

United Nations. Report of the Independent Expert for the United Nations Study on Violence Against Children. New York, General Assembly, United Nations, 2006. Available from: http:// www.unicef.org/violencestudy/reports/SG_violencestudy_en.pdf

\section{Correspondence to:}

Dra. Osvelia E. Rodríguez Luis

Jefa del Departamento de Escolar

Profesora Investigadora

Facultad de Odontología

Universidad Autónoma de Nuevo León

Calle Dr. Eduardo Aguirre Pequeño s/n

Colonia Mitras Centro

Nuevo León, C.P. 64460.

MÉXICO

Received: 06-08-2015

Accepted: 03-02-2016

Email: osveliardzl@yahoo.com.mx 